\title{
Hot Wire CVD for thin film triple junction cells and for ultrafast deposition of the SiN passivation layer on polycrystalline Si solar cells
}

\author{
R.E.I. Schropp*, R.H. Franken, H.D. Goldbach, Z.S. Houweling, H. Li, J.K. Rath, \\ J.W.A. Schüttauf, R.L. Stolk, V. Verlaan, C.H.M. van der Werf \\ Utrecht University, Faculty of Science, SID - Physics of Devices, P.O. Box 80.000, 3508 TA Utrecht, The Netherlands
}

Available online 15 June 2007

\begin{abstract}
We present recent progress on hot-wire deposited thin film solar cells and applications of silicon nitride. The cell efficiency reached for $\mu c-S i: H$ $\mathrm{n}-\mathrm{i}-\mathrm{p}$ solar cells on textured $\mathrm{Ag} / \mathrm{ZnO}$ presently is $8.5 \%$, in line with the state-of-the-art level for $\mu \mathrm{c}-\mathrm{Si}: \mathrm{H} \mathrm{n}-\mathrm{i}-\mathrm{p}$ 's for any method of deposition. Such cells, used in triple junction cells together with hot-wire deposited proto-Si:H and plasma-deposited SiGe:H, have reached 10.5\% efficiency. The single junction $\mu \mathrm{c}-\mathrm{Si}: \mathrm{H} \mathrm{n}-\mathrm{i}-\mathrm{p}$ cell is entirely stable under prolonged light soaking. The triple junction cell, including protocrystalline i-layers, is within $3 \%$ stable, due to the limited thicknesses of the two top cells. The application of $\mathrm{SiN}_{x}: \mathrm{H}$ at a deposition rate of $3 \mathrm{~nm} / \mathrm{s}$ to polycrystalline $\mathrm{Si}$ wafer solar cells has led to cells with $15.7 \%$ efficiency. We have also achieved record high deposition rates of $7.3 \mathrm{~nm} / \mathrm{s}$ for transparent and dense $\mathrm{SiN}_{x} ; \mathrm{H}$. Hot-wire $\mathrm{SiN}_{x}: \mathrm{H}$ is likely to be the first large commercial application of the Hot Wire CVD (Cat-CVD) technology.

(C) 2007 Elsevier B.V. All rights reserved.
\end{abstract}

Keywords: HWCVD; Solar cells; Multijunction; Efficiency; Stability; Silicon nitride

\section{Introduction}

The technology of Hot Wire Chemical Vapor Deposition or Catalytic CVD has made great progress during the last couple of years. Novel materials have been obtained with controlled properties and there is increasing evidence that large area continuous coating is feasible. This review discusses a number of examples of significant progress at our laboratory in the light of other achievements worldwide. Specifically, recent $p-i-n$ and $\mathrm{n}-\mathrm{i}-\mathrm{p}$ solar cells are highlighted, as well as the application of silicon nitride $\left(\mathrm{SiN}_{x}: \mathrm{H}\right)$ to polycrystalline solar cells.

The area of hot-wire deposited $\mathrm{SiN}_{x}: \mathrm{H}$ has shown great progress and this material is likely to be the first to be commercially applied. Silicon nitride is used in many applications. The proceedings of this conference alone show the successful use of $\mathrm{HW}-\mathrm{SiN}_{x}$ as encapsulation barrier against $\mathrm{H}_{2} \mathrm{O}$ and $\mathrm{O}_{2}$ (even on top of sensitive organic layers), as passivating dielectric in $\mathrm{AlGaN} / \mathrm{GaN}$ high mobility FETs, as a mechanically

\footnotetext{
* Corresponding author.

E-mail address: r.e.i.schropp@phys.uu.nl (R.E.I. Schropp).
}

strong material for microelectromechanical structures (MEMS), as a gate dielectric in TFTs, and as a passivating antireflective layer on polycrystalline solar cells.

\section{Thin film a-Si:H p-i-n solar cells}

Our 'standard' protocrystalline Si:H is deposited by HWCVD at a substrate temperature $T_{\text {sub }}$ of $250^{\circ} \mathrm{C}$. We use Ta filaments at a temperature of $1850{ }^{\circ} \mathrm{C}$, pure $\mathrm{SiH}_{4}$ feed gas and a process pressure of $0.02 \mathrm{mbar}$, resulting in a deposition rate of $1 \mathrm{~nm} / \mathrm{s}$ [1]. A fingerprint of the protocrystalline nature of this material is the narrow width of the first sharp peak in X-ray diffraction (XRD) [2]. For $\mathrm{p}-\mathrm{i}-\mathrm{n}$ type solar cells with a thickness of $300 \mathrm{~nm}$, deposited on Asahi U-type $\mathrm{SnO}_{2}:$ F-coated glass, under AM1.5 light-soaking conditions a light-induced decrease in fill factor (FF) of less than $10 \%$ has been observed [3]. We incorporated 200-nm thick HW-deposited protocrystalline cells in top-cell limited micromorph tandem cells in order to study their stability against light-induced degradation. The results reflect the potential of top-cell limited multibandgap thin film silicon micromorph tandem cells, which is important for high-yield outdoor application (as expressed in $\mathrm{kWh} / \mathrm{kWp} \mathrm{yr}$ ) [4]. In many 
Table 1

Performance of a $200 \mathrm{~nm} / 1000 \mathrm{~nm}$ HWCVD proto-Si/HWCVD $\mu \mathrm{c}-\mathrm{Si}: \mathrm{H}$ superstrate $\mathrm{p}-\mathrm{i}-\mathrm{n} / \mathrm{p}-\mathrm{i}-\mathrm{n}$ tandem cell on texture-etched $\mathrm{ZnO}$ (made at IPV Jülich) before and after light soaking

\begin{tabular}{lllll}
\hline Thicknesses 200/1000 nm & $V_{\text {oc }}(\mathrm{V})$ & $J_{\text {sc }}(\mathrm{mA} / \mathrm{cm} 2)$ & FF & $\eta(\%)$ \\
\hline Initial & 1.39 & 10.0 & 0.61 & 8.5 \\
Stable $(500 \mathrm{~h})$ & 1.39 & 10.1 & 0.60 & 8.5 \\
\hline
\end{tabular}

regions of the world, a positive correlation between operation temperature and light intensity exists, which is advantageous for the daily and annual energy yield of the top cell, but adverse for that of the bottom cell. This is due to differences in the temperature coefficients for the performance of the top and bottom cell. Therefore, top cell limited micromorph tandem cells will provide more energy per annum than bottom cell limited tandem cells [5], but this imposes stringent stability requirements on the top cell. Table 1 shows the performance and stability of a top-cell limited $\mathrm{p}-\mathrm{i}-\mathrm{n} / \mathrm{p}-\mathrm{i}-\mathrm{n}$ micromorph tandem cell on glass with texture-etched $\mathrm{ZnO}$ received from IPV Jülich. Both i-layers have been deposited by HWCVD. Between the short-circuit current densities generated by the two stacked cells a deliberate mismatch exists of $2.6 \mathrm{~mA} / \mathrm{cm}^{2}$. It is seen that this cell is perfectly stable even though the current-limiting amorphous $\mathrm{Si}$ cell dominates its fill factor $(\mathrm{FF})$. The high stability is due to the protocrystalline nature of the active layer in the top cell.

By increasing the filament temperature, we investigated by how much the deposition rate $r_{\mathrm{d}}$ for a-Si:H could be further increased in order to take advantage of the high deposition rate capability of HWCVD. Special precautions were taken to protect the Asahi $\mathrm{SnO}_{2}: \mathrm{F}$ coated substrates onto which the cells were deposited [1]. While the cells deposited at $1 \mathrm{~nm} / \mathrm{s}$ reached an initial efficiency of $8.9 \%\left(0.88 \mathrm{~V}, 14.2 \mathrm{~mA} / \mathrm{cm}^{2}, \mathrm{FF}=0.71\right)$, we achieved $8.5 \%$ at an $r_{\mathrm{d}}$ of $1.6 \mathrm{~nm} / \mathrm{s}, 8.1 \%$ efficiency at an $r_{\mathrm{d}}$ of $2.1 \mathrm{~nm} / \mathrm{s}$, and at an $r_{\mathrm{d}}$ of $3.2 \mathrm{~nm} / \mathrm{s}$ still a high efficiency of $7.5 \%$ was obtained. The i-layer deposition time under the last conditions is only $3-4 \mathrm{~min}$. Up to an $r_{\mathrm{d}}$ of $2.2 \mathrm{~nm} / \mathrm{s}$ the cells

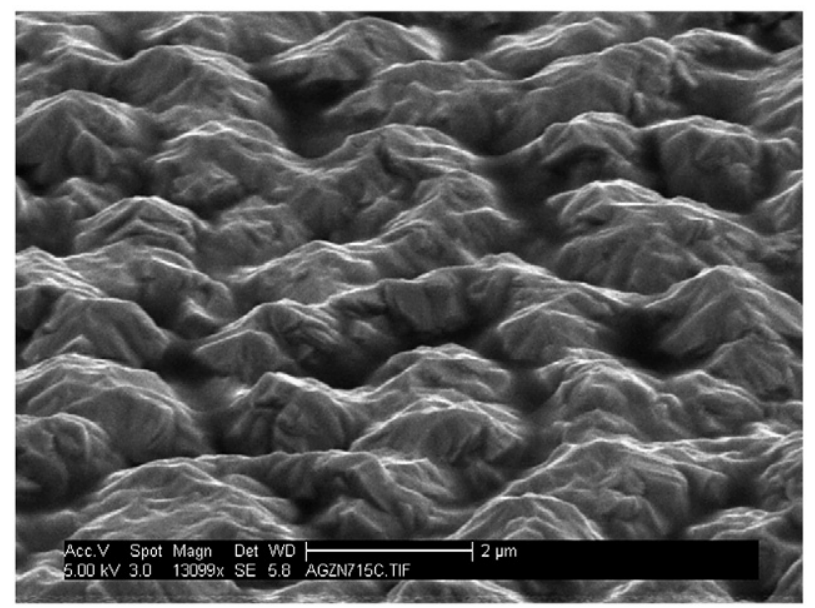

Fig. 1. The SEM morphology of an rf magnetron sputtered $\mathrm{Ag} / \mathrm{ZnO}$ textured back reflector.
Table 2

Present status of single junction HWCVD $\mu \mathrm{c}-\mathrm{Si}: \mathrm{H} \mathrm{n}-\mathrm{i}-\mathrm{p}$ solar cells at various laboratories

\begin{tabular}{lllll}
\hline Laboratory [ref] & $V_{\mathrm{oc}}(\mathrm{V})$ & $J_{\mathrm{sc}}\left(\mathrm{mA} / \mathrm{cm}^{2}\right)$ & $\mathrm{FF}$ & $\eta(\%)$ \\
\hline Utrecht [present work] & 0.545 & 23.39 & 0.668 & 8.52 \\
Jülich [8] & 0.542 & 19.9 & 0.69 & 7.5 \\
Kaiserslautern [9] & 0.522 & 21.6 & 0.66 & 7.3 \\
Ecole Polytechnique [10] & 0.42 & 20.7 & 0.59 & 5.1 \\
Gifu [11] & 0.550 & 11.32 & 0.56 & 3.49 \\
Unisolar [12] (non HWCVD) & 0.568 & 23.59 & 0.671 & 8.99 \\
\hline
\end{tabular}

behave quite stable: for cells with i-layers thinner than $300 \mathrm{~nm}$ (as in tandem cells) the degradation in FF is less than $10 \%$.

\section{Thin film $\mu c-S i: H ~ n-i-p$ cells and triple cells}

To enhance the efficiency in the $n-\mathrm{i}-\mathrm{p}$ configuration, we developed textured $\mathrm{Ag} / \mathrm{ZnO}$ back reflector layers on stainless steel substrates, using rf magnetron sputtering. An example of the surface morphology as observed with Scanning Electron Microscopy (SEM) is shown in Fig. 1. The $\mu \mathrm{c}-\mathrm{Si}$ :H i-layer is deposited at $270{ }^{\circ} \mathrm{C}$ by HWCVD. We use Ta filaments at a temperature of $1850{ }^{\circ} \mathrm{C}, \mathrm{a} \mathrm{SiH}_{4} / \mathrm{H}_{2}$ gas mixture at a flow ratio of $5 / 100$, and a pressure of $0.05 \mathrm{mbar}$, resulting in a deposition rate of $0.21 \mathrm{~nm} / \mathrm{s}$. The Raman ratio of crystallinity for this material is $40 \%$ and the crystallites have $10-20 \mathrm{~nm}$ sizes [6]. Further, we optimized the $\mu \mathrm{c}-\mathrm{Si}: \mathrm{H}$ n-type doped layer and the $\mathrm{n} / \mathrm{i}$ interface, and in addition we used $\mathrm{H}_{2} / \mathrm{SiH}_{4}$ ratio profiling during i-layer deposition [7]. Table 2 shows the present results in comparison with other data obtained on single junction $\mu \mathrm{c}-\mathrm{Si}: \mathrm{H} \mathrm{n}-\mathrm{i}-\mathrm{p}$ type cells on various substrates [8-12]. In our case, mainly due to the textured back reflector on stainless steel, the short-circuit current $J_{\mathrm{sc}}$ went up from the value of $15.2 \mathrm{~mA} / \mathrm{cm}^{2}$ obtained on plain stainless steel to $23.4 \mathrm{~mA} / \mathrm{cm}^{2}$ on textured $\mathrm{Ag} / \mathrm{ZnO}$. The spectral response curve is shown in Fig. 2. For comparison, Table 2 includes the latest best results obtained at United Solar Ovonic, LLC, for this type of cell as obtained using their 'modified VHF' technique. We believe that the obtained efficiency of $8.5 \%$ is a record value for hot-wire deposited $\mu \mathrm{c}-\mathrm{Si}: \mathrm{H}$

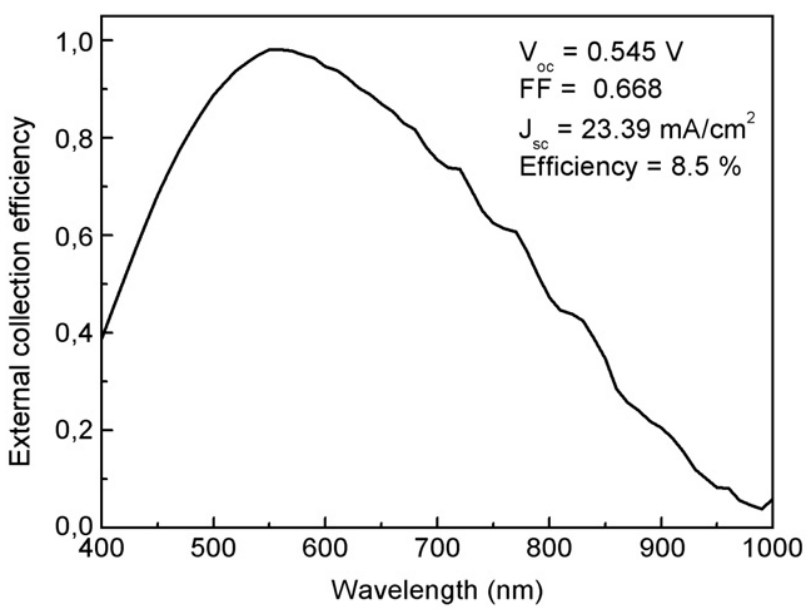

Fig. 2. Spectral response at $0 \mathrm{~V}$ of a $2-\mu \mathrm{m}$ thick $\mu \mathrm{c}-\mathrm{Si}: \mathrm{H}$ nip solar cell on textured $\mathrm{Ag} / \mathrm{ZnO}$. The AM1.5 cell parameters of the cell are listed. 
Table 3

Performance of HWCVD proto-Si/proto-SiGe/ HWCVD $\mu \mathrm{c}-\mathrm{Si}: H$ triple $\mathrm{n}-\mathrm{i}-\mathrm{p}$ / $\mathrm{n}-\mathrm{i}-\mathrm{p} / \mathrm{n}-\mathrm{i}-\mathrm{p}$ cells on textured $\mathrm{Ag} / \mathrm{ZnO}$ made in house and on substrates provided by Unisolar

\begin{tabular}{lllll}
\hline Triple junction & $V_{\mathrm{oc}}(\mathrm{V})$ & $J_{\mathrm{sc}}\left(\mathrm{mA} / \mathrm{cm}^{2}\right)$ & $\mathrm{FF}$ & $\eta(\%)$ \\
\hline Utrecht substrate & 2.030 & 7.84 & 0.657 & 10.45 \\
Unisolar substrate & 2.113 & 7.42 & 0.670 & 10.50 \\
\hline
\end{tabular}

$\mathrm{n}-\mathrm{i}-\mathrm{p}$ cells. Moreover, when this cell is exposed to continuous illumination at $100 \mathrm{~mW} / \mathrm{cm}^{2}$ with near-AM1.5 spectrum at a temperature of $50^{\circ} \mathrm{C}$, the cell shows to be totally stable (relative efficiency loss $\Delta \eta<0.6 \%$ after $500 \mathrm{~h}$ of light soaking).

The results on single junction $\mu \mathrm{c}-\mathrm{Si}: \mathrm{H}$ cells have been utilized in triple junction $n-\mathrm{i}-\mathrm{p}$ type cells. Previously, we have been optimizing triple junction cells of the type proto-Si $/ \mu \mathrm{c}-\mathrm{Si}$ : $\mathrm{H} / \mu \mathrm{c}-\mathrm{Si}: \mathrm{H}$, comprising active i-layers that were all deposited by HWCVD. In order to obtain sufficient current, however, this design leads to the use of very thick absorber layers, even when enhanced scattered back reflection is applied. For instance, if the top cell is $165 \mathrm{~nm}$ in order to generate $\sim 8 \mathrm{~mA} / \mathrm{cm}^{2}$, the middle cell and the bottom cell have to be made as thick as $\sim 2.4 \mu \mathrm{m}$ and $\sim 3.7 \mu \mathrm{m}$, respectively. The total thickness of over $6 \mu \mathrm{m}$ of $\mu \mathrm{c}-\mathrm{Si}: \mathrm{H}$ material is very large compared to the micromorph tandem concept. If the $\mu \mathrm{c}-\mathrm{Si}: \mathrm{H}$ middle cell is replaced by a proto-SiGe:H cell, then not only the middle cell can be made an order of magnitude thinner, but also the bottom $\mu c-S i: H$ cell can be made considerably thinner, since the SiGe:H middle cell does not absorb within exactly the same spectral region. A second important advantage is that a higher $V_{\text {oc }}$ of the triple cell can be obtained, because $\mathrm{SiGe}: \mathrm{H}$ has a higher band gap than $\mu \mathrm{c}-\mathrm{Si}: \mathrm{H}$. Thirdly, in principle the achievable conversion efficiency is higher, because all three band gaps are different and less photon energy is lost as heat. For the moment however, we use PECVD for the deposition of the middle cell, since it was readily available in our lab. The SiGe:H middle cell can very well be made by HWCVD, as is demonstrated by the good single junction cell results obtained by NREL [13].

We obtained $10.45 \%$ efficiency for a proto-Si/ proto-SiGe/ $\mu \mathrm{c}-\mathrm{Si}: \mathrm{H}$ triple junction cell on a textured $\mathrm{Ag} / \mathrm{ZnO}$ coated stainless steel substrate made in house. This compares very well with the $10.50 \%$ obtained on a United Solar Ovonic substrate in the same run. Table 3 shows the comparison between the cell results obtained on the two substrates. As can be seen from the $J_{\mathrm{sc}}$ versus FF trade off, the roughness of our homemade back reflectors is better optimized for $J_{\mathrm{sc}}$. Fig. 3 gives the spectral response data of the cell made on our in-house $\mathrm{Ag} / \mathrm{ZnO}$ coated substrate. It is worth noting that the three silicon cells stacked on top of each other are together less than $2.5 \mu \mathrm{m}$ thick.

This cell appears stable. Preliminary light soaking tests show that the relative degradation under $100 \mathrm{~mW} / \mathrm{cm}^{2}$ near-AM1.5 illumination at $50{ }^{\circ} \mathrm{C}$ is less than $3 \%$.

\section{Passivating and antireflective $\mathrm{HW}-\mathrm{SiN}_{x}: \mathrm{H}$}

We studied HW-deposited $\mathrm{SiN}_{x}$ as the top layer on cast polycrystalline silicon solar cells where it acts as antireflection coating (ARC) and simultaneously induces bulk and surface

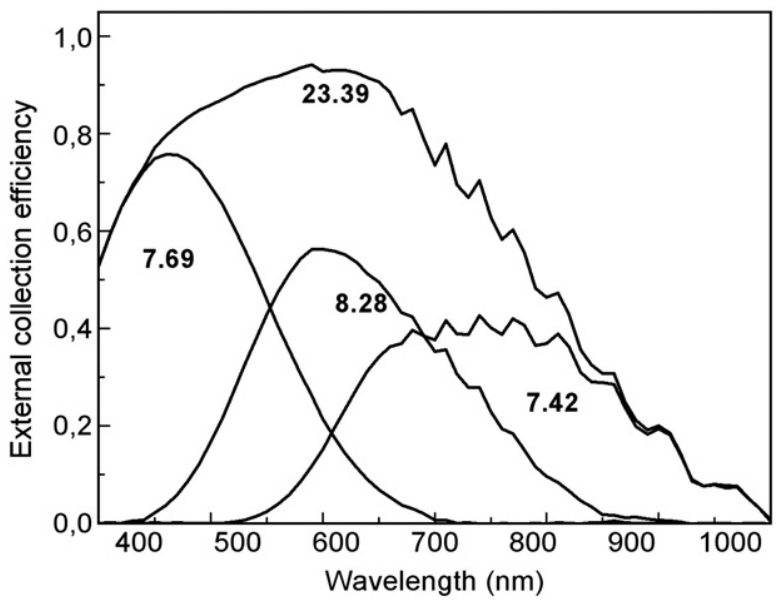

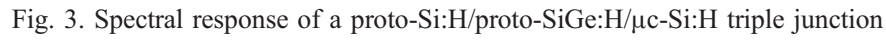
solar cell on a textured $\mathrm{Ag} / \mathrm{ZnO}$ back reflector.

passivation. The $\mathrm{SiN}_{x}: \mathrm{H}$ coatings are able to act as good ARCs because of their high and tunable refractive index in combination with a low extinction coefficient [14]. During a short high-temperature anneal ('firing' at $\sim 800{ }^{\circ} \mathrm{C}$ ), hydrogen is released from the $\mathrm{SiN}_{x}: \mathrm{H}$ layer and a part of it diffuses into the bulk of the polycrystalline Si wafer. Atomic $\mathrm{H}$ passivates the defects at grain boundaries enabling a significant enhancement of the cell performance.

Several series of cells with different $\mathrm{HW}-\mathrm{SiN}_{x}$ compositions were deposited on textured polycrystalline Si solar cells from ECN Solar Energy. The reference cells, made with microwave PECVD SiN $x$, reached an average open circuit voltage $V_{\text {oc }}$ of $606 \mathrm{mV}$. For the cells with $\mathrm{HW}-\mathrm{SiN}_{x}$, a maximum $V_{\text {oc }}$ of $604 \mathrm{mV}$ is reached for $\mathrm{N} / \mathrm{Si}$ values between 1.25 and 1.31. The maximum $J_{\mathrm{sc}}$ is found at $\mathrm{N} / \mathrm{Si}=1.31$. As a result the $V_{\mathrm{oc}} * J_{\mathrm{sc}}$ product, which is a good indicator of the cell quality, is optimal for the layers around a N/Si ratio of 1.31 .

Apart from the obtained high $V_{\mathrm{oc}}$ values, the internal quantum efficiency (IQE) measurements also illustrate good passivation properties for the cells with $\mathrm{HW}-\mathrm{SiN}_{x}$. In Fig. 4, the

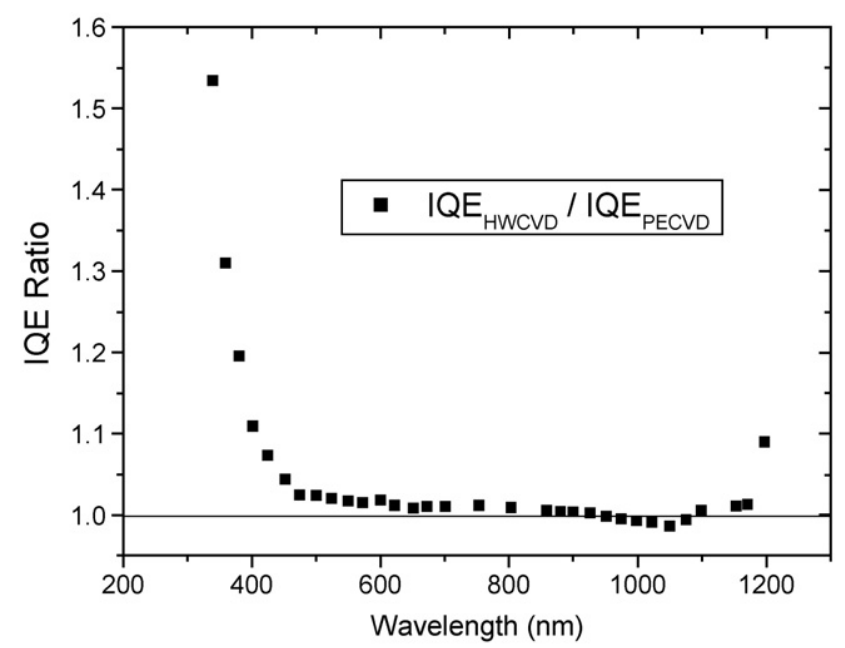

Fig. 4. The IQE ratio (HWCVD $\mathrm{SiN}_{x} /$ microwave PECVD $\mathrm{SiN}_{x}$ ) for the experiments with the ECN cells. 
IQE of the HW deposited $\mathrm{SiN}_{x}$ is plotted relative to the IQE of reference cells. The IQE values are identical in the infrared region, proving good bulk passivation. Interestingly, at wavelengths smaller than $600 \mathrm{~nm}$ the IQE of cells with a HW coating appears to be better. The superior blue response may originate either from the absence of substrate damage as caused by ion bombardment during PECVD, resulting in better surface passivation by the $\mathrm{HW}-\mathrm{SiN}_{x}$ layers, or it may be due to the very low extinction coefficient of the latter layers in the blue region of the spectrum.

The best cell reached a high efficiency of $15.7 \%$ whereas the best reference cell was at $16.1 \%$ efficiency. The $15.7 \%$ efficiency is a major improvement with respect to the value of $14.3 \%$ reported by us two years ago [15] and even more so with respect to the earlier data reported by Holt et al. [16] who applied HW $\mathrm{SiN}_{x}$ on String Ribbon substrates and achieved an efficiency of $12.4 \%$. The difference with the reference cells is found mainly in the FF. There still is room for improvement, since HW deposited $\mathrm{SiN}_{x}$ has a higher than usual mass density [17] $\left(\rho=2.93 \mathrm{~g} / \mathrm{cm}^{3}\right)$ and may therefore necessitate slightly different cell processing parameters, such as the firing conditions. Further, the homogeneity of the layers could play a role, since most cells are $6.5 \times 6.5 \mathrm{~cm}^{2}$, whereas the homogeneous zone in the presently available small HW reactor is only $5 \times 5 \mathrm{~cm}^{2}$. The design of specific equipment would thus improve the results. To our knowledge, never have hot-wire deposited $\mathrm{SiN}_{x}: \mathrm{H}$ layers achieved such a high performance as passivating antireflective coating.

Application of this high density, high deposition rate $\mathrm{SiN}_{x}$ as a dielectric layer is under study. For instance, Q. Wang et al. [18] have studied the HWCVD silicon nitride process because of the possible application of $\mathrm{SiN}_{x}$ as barrier layers. The presently obtained density of $2.93 \mathrm{~g} / \mathrm{cm}^{3}$ is even higher than that of silicon nitride prepared by high-temperature CVD with dichlorosilane at $760{ }^{\circ} \mathrm{C}$ [19] and higher than any plasma method. The low stress of $+50 \mathrm{MPa}$ (tensile) in the layers made at $3 \mathrm{~nm} / \mathrm{s}$, much lower than most PECVD deposited $\operatorname{SiN}_{x}$ samples, will be helpful, for instance, in plastic electronics. The electronic properties that we determined for this material are a fixed charge density $\sim 10^{16} \mathrm{~cm}^{-3}$, an interface state density of $\sim 10^{10} \mathrm{~cm}^{-2}$, as determined from the small hysteresis between the positive and negative sweep direction in the $\mathrm{C}-\mathrm{V}$ measurement, a breakdown field of $2.5 \mathrm{MV} / \mathrm{cm}$ (thickness $300 \mathrm{~nm}$ ) and the etch rate in a $16 \mathrm{BFH}$ etch solution of 5 parts of $40 \%$ $\mathrm{NH}_{4} \mathrm{~F}$ with 1 part $49.5 \% \mathrm{HF}$ is $8 \mathrm{~nm} / \mathrm{min}$, much better than that for PECVD layers made at a significantly lower deposition rate [20]. The electrical breakdown field is expected to improve when more N-rich layers or thinner layers are used.

Next, we also investigated hot-wire deposition of $\mathrm{SiN}_{x}$ at ultra high deposition rates of $>7 \mathrm{~nm} / \mathrm{s}$. In order to increase the deposition rate while keeping a constant $\mathrm{N} / \mathrm{Si}$ ratio in the film, it is necessary to improve the ammonia decomposition rate while increasing the silane flow. This is done by using a high filament temperature $\left(2300{ }^{\circ} \mathrm{C}\right)$ and by increasing the deposition pressure. This leads to sufficiently high nitrogen incorporation.
Despite this high deposition rate, the $\mathrm{SiN}_{x}$ layers still possess a relatively high mass density of $2.6 \mathrm{~g} / \mathrm{cm}^{3}$ and good thermal stability. This silicon nitride deposited at high deposition rate shows good potential for application as the dielectric layer in various applications.

\section{Acknowledgments}

We thank United Solar Ovonic LLC for providing stainless steel substrates with textured $\mathrm{Ag} / \mathrm{ZnO}$ coatings and $\mathrm{FZ}$ Jülich for providing texture-etched $\mathrm{ZnO}$. We also thank Gerard van der Mark and Arjen Bink for extensive technical assistance with the sputter tool. We thank our colleagues at ECN Solar Energy for processing the polycrystalline solar cells and Unaxis France for the stress measurement of our $\operatorname{SiN}_{x}$. The research described in this paper was financially supported by the Netherlands Agency for Energy and the Environment (SenterNovem).

\section{References}

[1] R.E.I. Schropp, M.K. van Veen, C.H.M. van der Werf, D.L. Williamson, A.H. Mahan, Mater. Res. Soc. Symp. Proc. 808 (2004) A8.4.1.

[2] D. Williamson, Mater. Res. Soc. Symp. Proc. 557 (1999) 251.

[3] R.H. Franken, C.H.M. van der Werf, J.K. Rath, R.E.I. Schropp, Thin Solid Films 501 (1-2) (2006) 47.

[4] R.E.I. Schropp, R.H.J. Franken, A. Gordijn, H. Li, J. Löffler, J.K. Rath, R. Stolk, M. van Veen, C.H.M. van der Werf, Proceedings of the 31st IEEE PVSC Conference, 2005.

[5] A. Nakajima, M. Ichikawa, T. Sawada, M. Yoshimi, K. Yamamoto, Jpn. J. Appl. Phys. 43 (9A/B) (2004) L1162.

[6] M.K. van Veen, C.H.M. van der Werf, J.K. Rath, R.E.I. Schropp, Thin Solid Films 430 (2003) 216.

[7] H. Li, R.H. Franken, R.L. Stolk, C.H.M. van der Werf, J.K. Rath, R.E.I. Schropp, these Proceedings.

[8] S. Klein, F. Finger, R. Carius, O. Kluth, A.L. Baia Neto, H. Wagner, M. Stutzmann, Proceedings of the 17th ECPVSEC, Munich, 2001, p. 2965.

[9] B. Schröder, M. Kupich, P. Kumar, D. Grunsky, (2007-this issue) pii: S0040-6090(07)00925-X.

[10] C. Niikura, Y. Poissant, M.E. Gueunier, J.P. Kleider, J.E. Bourée, J. NonCryst. Solids 299-302 (2002) 1179.

[11] K. Mizuno, S. Ogawa, M. Okabe, T. Itoh, N. Yoshida, S. Nonomura, this conf., HW4-23.

[12] B. Yan, G. Yue, J.M. Owens, J. Yang, S. Guha, Proceedings of the 4th WCPEC, Waikoloa, HI, 2006.

[13] Y. Xu, A.H. Mahan, L.M. Gedvillas, R.C. Reedy, H. Branz, Thin Solid Films 501 (2006) 198.

[14] P. Doshi, G.E. Jellison, R. Hezel, Proc. 14th Photovoltaic Solar energy Conference. Barcelona, 1997, p. 684.

[15] C.H.M. van der Werf, H.D. Goldbach, J. Loffler, A. Scarfo, A.M.C. Kylner, B. Stannowski, W.M. ArnoldBik, A. Weeber, H.C. Rieffe, W.J. Soppe, J.K. Rath, R.E.I. Schropp, Thin Solid Films 501 (2006) 51.

[16] J.K. Holt, D.G. Goodwin, A.M. Gabor, F. Jaing, M. Stavola, H. Atwater, Thin Solid Films 430 (2003) 37.

[17] J. Hong, W.M.M. Kessels, W.J. Soppe, A.W. Weeber, W.M. Arnoldbik, M.C.M. van der Sanden, J. Vac. Sci. Techno., B 21 (2003) 2123.

[18] Q. Wang, S. Ward, L. Gedvillas, B. Keyes, E. Sanchez, S. Wang, Appl. Phys. Lett. 84 (3) (2004) 338.

[19] H. Matsumura, A. Masuda, H. Umemoto, Thin Solid Films 501 (2006) 58.

[20] A. Masuda, H. Umemoto, H. Matsumura, Thin Solid Films 501 (2006) 149. 